\title{
Nutritional potential of differently processed Cajanus cajan leaves on nutrient digestibility and nitrogen utilization of West African dwarf growing rams fed Panicum maximum
}

Adebisi, I. A., Ajibike, A. B., Okunlola, O. O., Alalade, J. A., Amusa, H. O., Oladepo, O., Adeniyi, A. O. and Mustapha, T. B.

Department of Animal Health and Production Technology,

Oyo State College of Agriculture and Technology,

P. M. B 10, Igboora, Oyo State, Nigeria

Corresponding author: *ademolaibrahim01@yahoo.com;

Abstract

$+234-806-073-9507$

Browse legume plants particularly pigeon pea forage generates a lot of underutilized leaves which if properly harnessed can be a cheaper source of nutrients for small ruminant animal production, during dry season feed shortages. In this study, the nutrient digestibility and nitrogen utilization of West African dwarf growing rams fed differently processed Cajanus cajan leaves and Panicum maximum basal diet for 56 days feeding trial. A total of sixteen (16) growing WAD rams between 6 - 9 months with an average body weight of $7.00-12.00 \mathrm{~kg}$ were randomly allocated to 4 treatments with 4 rams each and 2 rams per replicate. The experimental diet was fed at 3\% body weight of individual ram while fresh, wilted, and dried forms of Cajanus cajan leaves supplemented at varied inclusion levels $(0 \%, 30 \%$ fresh, 30\% wilted and $30 \%$ dried) with Panicum maximum. There were significant $(P<0.05)$ differences in all parameters determined on nutrient digestibility across the dietary treatments. Animals maintained on $T_{4}$ (70\% Panicum maximum and 30\% dried Cajanus cajan leaves) had the highest dry matter digestibility (60.46\%), while the lowest value (48.56\%) for DMD was recorded in $T_{1}$ diet. Rams fed $T_{2}$ diet had the highest mean crude protein digestibility (CPD) value of $11.30 \%$, followed by $T_{2}(10.68 \%), 10.02 \%$ for $T_{1}$, while $T_{4}$ diet had the lowest mean CPD of $9.21 \%$. Rams fed $T_{1}$ diet had the highest mean crude fibre digestibility (CFD) value of $37.65 \%$, while 35.03, 33.18 and 32.71 were recorded for $T_{4}, T_{2}$ and $T_{3}$ diet respectively. $T_{4}$ was observed to have the highest mean ash digestibility value of $17.07 \%$ with $T_{3}, T_{1}$ and $T_{2}$ having the value of 16.02, 14.28 and 13.36 respectively. There were significant $(P<0.05)$ differences in all parameters determined on nitrogen utilization across the dietary treatments. Ram maintained on $T_{2}$ diet had the highest mean intake of $4.42 \mathrm{~g} / \mathrm{d}$ while $T_{1}$ diet had the lowest mean value of $2.64 \mathrm{~g} / \mathrm{d}$. The lowest mean nitrogen balance (NB) of $0.43 \mathrm{~g} / \mathrm{d}$ was observed in rams fed $T_{1}$ diet while rams on $T_{2}$ diet had the highest $N B$ value of $2.18 \mathrm{~g} / \mathrm{d}$. Rams fed $T_{4}$ diet had the highest faecal nitrogen value of $2.14 \mathrm{~g} / \mathrm{d}$. However, rams maintained on $T_{4}$ diet had the highest value urinary nitrogen of $1.07 \mathrm{~g} / \mathrm{d}$. The nitrogen utilization fluctuated significantly $(P<0.05)$ across the dietary treatments. It can be concluded that supplementation of fresh Cajanus cajan forages at $30 \%$ inclusion with Panicum maximum at $70 \%$ for growing rams can enhance nutrient utilization in terms of crude protein digestibility and nitrogen utilization without any deleterious effects on the animals.

Keywords: Tropical grass, Processed Cajanus cajan forages, WAD rams, Digestibility, Nitrogen utilization.

\section{Introduction}

Ruminants are important livestock species in Nigeria and form an integral part in smallholder farming systems as they provide adequate nutrients required as food. Small ruminants, in particular, are useful to humans during periods of cyclical and unpredictable food shortages (Birteeb et al., 


\section{Nutritional potential of differently processed Cajanus cajan leaves}

2012). Despite the importance of these animals, poor nutrition, especially during the dry season, has been indicated as a major threat to their sustainable production (Lamidi and Ologbose, 2014). An adequate supply of fodder is, however, essential for the development of livestock and a major way to overcome dry season fodder shortage is to source for crop residues during the cropping season and preserve for dry season feeding. Poor livestock production in the developing countries, particularly under smallholder farmers condition, is attributed to over-dependence on low digestible, poor quality and inadequate feed supply from natural pastures. Sometimes, feed from natural pastures especially at maturity cannot even meet the maintenance requirements of the animals, and to address this situation, fodder trees, shrubs and herbaceous legumes have been used as supplementary feed for ruminants (Aregheore and Perera 2004; Hassen et al., 2006; Fadiyimu et al., 2010; Abegunde and Akinsoyinu 2011; Barakat et al., 2013). Therefore, there is a need to look for protein sources that farmers could get from their own farm with minimum cost. One potential way for increasing the availability of feeds for smallholder farmers could be through the use of fodder trees and shrub legumes. Pigeon pea (Cajanus cajan) is one of such fodder legumes whose leaves are an important fodder and serves as a valuable source of feed for farm animals (Foster $e t$ al., 2009). Tropical browse plants such as Pigeon pea (Cajanus cajan) is a multipurpose nitrogen-fixing crop that provides the seed as human food and poultry feed, the leaves and young stems as animal fodder for the subsistence farmers (Lorgyer, 2009).

Panicum maximum also called guinea grass and tangayika grass (FAO, 2003) is a highly productive, palatable, persistent and acceptable grass by ruminants. It can be fed to livestock solely or with concentrates or legumes. To preserve for future use and to reduce the effects of some inherent antinutritive factors present in the leaves of some browse species either drying or wilting is employed at the On-farm level of production.

This study was therefore designed to investigate the nutrient digestibility and nitrogen utilization by West African dwarf growing rams fed Panicum maximum supplemented with differently processed Cajanus cajan leaves.

\section{Materials and methods Experimental site and animals}

The experiment was carried out at the Sheep and Goat Unit, Teaching and Research Farm, Oyo State College of Agriculture and Technology, Igboora. Sixteen (16) growing West African dwarf rams weighing between $7.00-12.00 \mathrm{~kg}$ and of $6-9$ months of age were used. The animals were allowed to acclimatize for two weeks and treated against ectoparasites and endoparasites prior to the commencement of the experiment.

\section{Harvesting and processing of experimental diets}

The forages were harvested from pasture demonstration plot of the college farm. Cajanus cajan leaves and Panicum maximum were cut at a height of $30 \mathrm{~cm}$ above the ground level at 50\% flowering stage to allow for good re-growth. Cajanus cajan leaves including twigs and petioles were harvested and sun-dried for four to five days by spreading on a concrete floor and turning thoroughly to facilitate uniform drying for saving storage while the wilting was carried out for 14hours between 3.00 pm - 8.00 am under the shade a day preceding the feeding day. Panicum maximum was harvested daily (Zero grazing) and chopped manually into $3-5 \mathrm{~cm}$ length before feeding. 
Adebisi, Ajibike, Okunlola, Alalade, Amusa, Oladepo, Adeniyi and Mustapha

\section{Experimental layout, design and feeding} method

The animals were allocated by weight into four treatments of four rams per treatment and two animals as replicate in a completely randomized design (CRD). The experimental diets' composition is $\mathrm{T}_{1}(100 \%$ Panicum maximum solely), $\mathrm{T}_{2} \quad(70 \%$ Panicum maximum and 30\% fresh Cajanus cajan leaves), $\mathrm{T}_{3}$ (70\% Panicum maximum and $30 \%$ wilted Cajanus cajan leaves) and $\mathrm{T}_{4}$ (70\% Panicum maximum and 30\% dried Cajanus cajan leaves). The chemical composition of fresh, wilted, and dried Cajanus cajan leaves and Panicum maximum are shown in Table 1. Each group of animals was assigned to an experimental diet and were fed ad libitum while fresh water was made available.

\section{Data collection and analysis}

Urine and faeces were collected separately from each animal daily throughout the last seven days of the experiment in metabolic cages. The faeces sample collected were oven-dried at $80^{\circ} \mathrm{C}$ until a constant weight was reached. The urinary outputs were collected in sample bottles with a plastic cover containing $20 \%$ dilute tetraoxosulphate (IV) acid, and stored at $20^{\circ} \mathrm{C}$ for analysis. The faecal samples were chemically analyzed using A.O.A.C procedure (AOAC, 1995). All nutrient digestibility and nitrogen utilization data obtained were subject to one-way analysis of variance (SAS, 1999). Differences among the means were separate using Duncan's multiple range test (Duncan, 1955).

Table 1: Chemical composition of fresh, wilted, and dried maximum

\begin{tabular}{lcccc}
\hline Parameters & $\begin{array}{c}\text { Fresh Cajanus } \\
\text { cajan } \text { leaves }\end{array}$ & $\begin{array}{c}\text { Wilted Cajanus } \\
\text { cajan leaves }\end{array}$ & $\begin{array}{c}\text { Dried Cajanus } \\
\text { cajan leaves }\end{array}$ & $\begin{array}{c}\text { Panicum } \\
\text { maximum }\end{array}$ \\
\hline DM & 44.50 & 86.60 & 91.48 & 32.80 \\
CP & 22.31 & 21.20 & 19.00 & 5.30 \\
CF & 25.26 & 26.86 & 27.12 & 22.20 \\
EE & 4.79 & 4.64 & 4.50 & 2.90 \\
ASH & 9.12 & 9.32 & 9.45 & 3.30 \\
NDF & 33.20 & 33.52 & 33.83 & 51.00 \\
ADF & 29.50 & 29.47 & 29.40 & 31.00 \\
Lignin & 10.12 & 11.01 & 12.40 & 13.47 \\
NFE & 15.98 & 24.58 & 8.52 & 66.00 \\
M.E (Kcal/Kg) & 3427.07 & 3804.98 & 3206.84 & 4223.06 \\
\hline DM=Dry matter, CP=Crude protein, CF=Crude fib & re, EE=Ether extract, NDF= Neutral detergent fibre, \\
ADF=Acid detergent fibre, NFE=Nitrogen free extract and ME= Metabolizable energy
\end{tabular}

\section{Results and discussion}

The proximate composition and fibre fractions percentage of different forms of Cajanus cajan forages and Panicum maximum is presented in Table 1 . The DM values ranged from $44.50 \%$ in the fresh Cajanus cajan leaves to $91.48 \%$ in the dried Cajanus cajan leaves. The values for the DM content of different forms of Cajanus cajan leaves is at variance with that reported for indigenous multipurpose trees in Nigeria (Babayemi, 2006, Anele et $a l ., 2009)$ which may be attributable to the maturity of the leaves used in this study to feed the growing rams. The fresh Cajanus cajan leaves had the highest crude protein (CP) content of $22.31 \%$ with the dried Cajanus cajan leaves having the least value of $19.00 \%$. The proportion of CP obtained in the different forms of Cajanus cajan leaves used in the study were within the range (21 to $38 \%)$ reported in the literature (Cook et al., 2005; Belete et al. 2013; Diriba et al., 2013). Variations observed across literature could be due to the concentration of plant constituents, which 


\section{Nutritional potential of differently processed Cajanus cajan leaves}

could vary from one geographical location to another depending on the age of the plant, differences in topographical factors, varietal differences, and the nutrient concentrations of the soil as well as processing methods. The range of the $\mathrm{CP}$ values observed across different forms of Cajanus cajan forages in this study could however enhance the intake of this legume browse plant by ruminants as they could supply critical nutrients needed to enhance ruminal microbial growth and fermentation of feed (Raghuvanis et al., 2007). In general, all forms of Cajanus cajan forages had a CP concentration more than 7\% which indicates their great nutritive value in terms of CP. Norton (1994) reported that feeds with less than $6 \%$ of CP levels are unlikely to provide the minimum ammonia levels required for maximum microbial growth in the rumen. The ether extract (EE) values which represented the crude fat content was higher in a fresh form of Cajanus cajan leaves and was also richer in fat compared to the wilted and dried forms. The EE values recorded for different forms Cajanus cajan leaves, however, showed that they contained adequate crude fat to satisfy the energy requirement of ruminant animals for productive purposes. Feedstuffs having a crude fat value of 1-2\% have been found sufficient to maintain good health by reducing the risk of diseases and ageing caused by its excess consumption (Sodamade et al., 2013). Variations were observed in the fibre fractions composition of different forms of Cajanus cajan leaves. The dried form had the highest value $(33.83 \%)$ for neutral detergent fibre (NDF) with least values in the fresh form $(33.20 \%)$, while the acid detergent fibre (ADF) recorded the highest and lowest values of $29.50 \%$ and $29.40 \%$ for fresh and dried forms of Cajanus cajan leaves, respectively. The NDF concentration of the different forms of Cajanus cajan leaves was below $60 \%$ which has been reported as the threshold level of NDF in tropical plants beyond which feed intake of ruminants is affected (Meissner et al., 1991). The NDF is the best indicator to predict fodder quality as it is related to the intake potential of the fodder and energy value. The low fibre content of different forms of Cajanus cajan leaves, suggests it as a potential and important source of readily fermentable carbohydrates in ruminant feeds. The nutrient digestibility summary of growing West African dwarf rams fed Panicum maximum supplemented with differently processed Cajanus cajan leaves are shown in Table 2. The highest DM digestibility $(60.46 \%)$ was observed in $\mathrm{T}_{4}$ diet $(70 \%$ Panicum maximum and 30\% dried Cajanus cajan leaves) which could be enough to meet the production and maintenance requirements of growing rams. There were significant differences $(P<0.05)$ in the DM digestibility values measured across the dietary treatments. The digestibility values obtained in this study might be evidence of proper utilization of dried Cajanus cajan leaves by (WAD) rams than sole Panicum maximum. The progressive increase in DM digestibility as the level of supplements inclusion increased probably reflects the better palatability and or acceptability of different forms of Cajanus cajan leaves by WAD rams than Panicum maximum solely. The CP digestibility of the diet ranged from $9.21 \%\left(\mathrm{~T}_{4}\right)-11.30 \%\left(\mathrm{~T}_{2}\right)$, and this was adequate to support the maintenance requirement, growth and performance of small ruminants. The $\mathrm{CP}$ digestibility content was in line with the report of Getachew et al. (2000) that the browse plants are higher in crude protein than tropical grasses and roughages.

However, the CP digestibility content of the plants studied were all above $8 \%$ (CPD) required to satisfy the maintenance requirement of ruminant animals (Norton, 2003), and above the minimum level necessary to provide sufficient nitrogen 
Adebisi, Ajibike, Okunlola, Alalade, Amusa, Oladepo, Adeniyi and Mustapha

required by rumen micro-organisms to support optimum activity (McDonald et al., 2002). The high level of CP digestibility recorded across treatments in the study indicates that processed Cajanus cajan leaves in different forms could serve as potential protein supplements that will enhance the intake and utilization of lowquality grass and fibrous crop residues by ruminants. The values of $\mathrm{CF}$ digestibility content ranged from $32.71 \%\left(\mathrm{~T}_{3}\right)-37.65 \%$ $\left(\mathrm{T}_{1}\right)$, which was very good as it will have high hemicelluloses and cellulose for better utilization by the system of the ruminant animals. The ash digestibility content ranged from $13.36 \%\left(\mathrm{~T}_{2}\right)-17.07 \%\left(\mathrm{~T}_{4}\right)$, which indicated that ash content was useful in assessing the quality grading of leaves, and also gives an idea of the number of mineral elements present in the leaves (Smart, 1996). The recorded values in this study were higher than $10.90 \%$ reported by
Ibeawuchi et al. (2002), thus, making Cajanus cajan leaves in different forms a better source of essential valuable and useful minerals needed for good metabolic which will enhance small ruminants production. The highest EE digestibility $(2.13 \%)$ was recorded for rams fed $\mathrm{T}_{2}$ diet while $\mathrm{T}_{1}$ has the least of $2.05 \%$; these values were below the range of $4-10 \%$ ether extract recommended by Preston and Leng (1995) for small ruminants. The highest NDF, ADF and ADL digestibility of $74.60 \%, 58.31 \%$ and $20.55 \%$ was recorded in $\mathrm{T}_{2}, \mathrm{~T}_{4}$ and $\mathrm{T}_{2}$, respectively, which could be attributed to the fact that as the plant matures, the fibre fraction also increases. This observation was in accordance with the findings of McDonald et al. 1998, who reported that with an advance in forage plant maturity; there is an attendant increase in its dry matter, ADF, NDF and NFE content with an appropriate decrease in its crude protein.

Table 2: Nutrient digestibility of West African dwarf growing rams fed Panicum maximum supplemented with differently processed Cajanus Cajan Leaves

\begin{tabular}{cccccc}
\hline Parameters & $\mathbf{T}_{\mathbf{1}}$ & $\mathbf{T}_{\mathbf{2}}$ & $\mathbf{T}_{\mathbf{3}}$ & $\mathbf{T}_{\mathbf{4}}$ & $\mathbf{S E M}$ \\
\hline DM Digestibility & $48.56^{\mathrm{d}}$ & $50.92^{\mathrm{c}}$ & $57.85^{\mathrm{b}}$ & $60.46^{\mathrm{a}}$ & 2.43 \\
CP Digestibility & $10.02^{\mathrm{c}}$ & $11.30^{\mathrm{a}}$ & $10.68^{\mathrm{b}}$ & $9.21^{\mathrm{d}}$ & 0.86 \\
CF Digestibility & $37.65^{\mathrm{a}}$ & $33.18^{\mathrm{c}}$ & $32.71^{\mathrm{cd}}$ & $35.03^{\mathrm{b}}$ & 2.50 \\
Ash Digestibility & $14.28^{\mathrm{c}}$ & $13.36^{\mathrm{d}}$ & $16.02^{\mathrm{b}}$ & $17.07^{\mathrm{a}}$ & 0.34 \\
EE Digestibility & $2.05^{\mathrm{c}}$ & $2.13^{\mathrm{a}}$ & $2.08^{\mathrm{b}}$ & $2.10^{\mathrm{b}}$ & 0.13 \\
NDF Digestibility & $60.54^{\mathrm{d}}$ & $74.60^{\mathrm{a}}$ & $67.20^{\mathrm{b}}$ & $64.03^{\mathrm{c}}$ & 2.59 \\
ADF Digestibility & $53.22^{\mathrm{c}}$ & $56.83^{\mathrm{b}}$ & $52.91^{\mathrm{cd}}$ & $58.31^{\mathrm{a}}$ & 1.15 \\
ADL Digestibility & $10.71^{\mathrm{d}}$ & $20.55^{\mathrm{a}}$ & $19.93^{\mathrm{b}}$ & $15.07^{\mathrm{c}}$ & 0.97 \\
\hline DM=Dry matter; CP=Crude protein; $\mathrm{CF}=$ Crude fibre; NFE=Nitrogen free extract; NDF=Neutral detergent fibre; \\
ADF= acid detergent fibre. ${ }^{\text {a b c d }}$ Means on the same row with different superscript are significantly \\
different $(\mathrm{P}<0.05)$.
\end{tabular}

The nitrogen utilization summary of growing West African dwarf rams fed Panicum maximum supplemented with differently processed Cajanus cajan leaves are shown in Table 2. The nitrogen intake $(4.42 \mathrm{~g} / \mathrm{d})$ of rams fed $\mathrm{T}_{2}$ diet was higher ( $>0.05)$ than nitrogen intakes of rams fed $\mathrm{T}_{1}, \mathrm{~T}_{3}$ and $\mathrm{T}_{4}$ diets. Animals fed $\mathrm{T}_{4}$ diet had the highest value $(2.14 \mathrm{~g} / \mathrm{d})$ of faecal nitrogen output than other treatment groups. The percentage of nitrogen utilization recorded in this study ranged between 16.29 to $49.32 \%$, which fell within the range of 17 to $79 \%$ reported by Okoruwa and Adewumi (2010) for West African dwarf sheep. Fajemisin et al. (2012) might attribute the observed values to feeding intake, protein quality and digestibility of the diet while observed nitrogen retention values corroborated the 


\section{Nutritional potential of differently processed Cajanus cajan leaves}

reported values. However, the nitrogen utilization values observed in this study was favourably compared to the values reported by Jokthan et al. (2009) for Yankasa sheep fed rice straw supplemented with pigeon pea forage. Higher nitrogen intake of $\mathrm{T}_{2}$ rams could be that the diet contained more crude protein $(\mathrm{CP})$ than the other dietary treatments. The observed increase in faecal nitrogen output noted in $\mathrm{T}_{4}$ diet could be attributed to inhibitory effects of residual toxic and astringent factor condensed tannins (CTs) associated with Cajanus cajan forage. Okoruwa et al.
(2013) made a similar observation with West African dwarf sheep fed pineapple waste. Hence, the more the nitrogen consumed and digested the more the nitrogen retained and vice versa (Okeniyi et al., 2010). Based on this, it is logical to infer that the superior nitrogen absorbed and retained by $T_{2}$ rams might be due to the higher nitrogen intake $(4.42 \mathrm{~g} / \mathrm{d})$. Higher nitrogen retention by the animals fed $\mathrm{T}_{2}$ diet indicate superior nitrogen utilization efficiency of $30 \%$ fresh Cajanus cajan leaves and $70 \%$ Panicum maximum

Table 3: Nitrogen utilization of West African dwarf growing rams fed Panicum maximum supplemented with differently processed Cajanus Cajan Leaves

\begin{tabular}{cccccc}
\hline Parameters & $\mathbf{T}_{1}$ & $\mathbf{T}_{2}$ & $\mathbf{T}_{3}$ & $\mathbf{T}_{4}$ & SEM \\
\hline Nitrogen intake $(\mathrm{g} / \mathrm{d})$ & $2.64^{\mathrm{b}}$ & $4.42^{\mathrm{a}}$ & $4.24^{\mathrm{a}}$ & $3.89^{\mathrm{ab}}$ & 0.35 \\
Faecal nitrogen $(\mathrm{g} / \mathrm{d})$ & $1.96^{\mathrm{ab}}$ & $1.92^{\mathrm{ab}}$ & $1.85^{\mathrm{b}}$ & $2.14^{\mathrm{a}}$ & 0.05 \\
Urinary nitrogen $(\mathrm{g} / \mathrm{d})$ & $0.25^{\mathrm{c}}$ & $0.32^{\mathrm{bc}}$ & $0.57^{\mathrm{b}}$ & $1.07^{\mathrm{a}}$ & 0.16 \\
$\begin{array}{c}\text { Total N output }(\mathrm{g} / \mathrm{d}) \\
\text { Nitrogen balance } \\
\text { (g/d) }\end{array}$ & 2.21 & 2.24 & 2.42 & 3.21 & 0.21 \\
$\begin{array}{c}\text { Nitrogen utilization } \\
(\%)\end{array}$ & $0.43^{\mathrm{cd}}$ & $2.18^{\mathrm{a}}$ & $1.82^{\mathrm{b}}$ & $0.68^{\mathrm{c}}$ & 0.37 \\
& & & & & \\
& & & & & \\
\end{tabular}

abcd means on the same row with different superscript are significantly different $(p<0.05)$.

\section{Conclusion}

In conclusion, the study reveals that different forms of Cajanus cajan forages are highly digestible and contain high concentrations of crude protein and low cell wall contents that could make it a good source of nutritional supplement in the diet of ruminants thereby minimizing nutrient deficiencies faced by ruminant grazing animals especially during the dry season. The findings from this study, also revealed that Panicum maximum supplemented with differently processed Cajanus cajan leaves has a good nutrient profile for feeding small ruminant animals. Growing rams fed $70 \%$ Panicum maximum and 30\% fresh Cajanus cajan leaves showed the $T_{2}$ is palatable, accepted and increase rams' nutrient digestibility and nitrogen utilization. Hence, incorporating fresh Cajanus cajan leaves into growing ram diets can solve the problem of inadequate nutrients due to a shortage of feed during the dry season faced by smallholder ruminant farmers and enhance their performance characteristics.

\section{Recommendation}

It can be recommended from this research that $30 \%$ fresh form of Cajanus cajan leaves and 70\% Panicum maximum should be incorporated into WAD sheep diet, as either basal or supplement diet, for better nutrient digestibility and nitrogen utilization to alleviate the nutrient requirement and body weight loses that are usually experienced during dry period. 
Adebisi, Ajibike, Okunlola, Alalade, Amusa, Oladepo, Adeniyi and Mustapha

References

Anele, U. Y., Arigbede, O. M., Südekum, K. H., Oni, O. Jolaosho, A. O., Olanite, J. A., and Akinola, O. B. 2009. Seasonal Chemical Composition, In-Vitro Fermentation and In-Sacco Dry Matter degradation of Four Indigenous Multipurpose Tree Species in Nigeria. Animal Feed Science and Technology, 154(1), 47-57.

A.O.A.C. 1995. Official Methods of Analysis. 15 th Edition. Association of Official Analytical Chemists. Washington, DC. Pp: 68-69

Babayemi, O. J. 2006. Ant-nutritional Factors, Nutritive Value and InVitro Gas Production of Foliage and Fruit of Enterolobium cyclocarpum. World Journal of Zoology, 1(2), 113-117.

Belete, S., Abubeker, H., Abule, E. and Nura, A. 2013. Performance of Arsi-Bale kids supplemented with graded levels of pigeon pea in dry season in Mid Rift valley of Ethiopia. African Journal of Agricultural Research, 8(20): 2366-2370.

Cook, B. G., Pengelly, B. C., Brown, S. D., Donnelly, J. L., Eagles, D. A., Franco, M. A., Hanson, Mullen. J., B. F., Partridge, I. J., Peters, $M$ and Schultze-Kraft, R. 2005. Tropical forages: an interactive selection tool Australia. Journal of Environmental Management, 113: 341-346.

Diriba, G., Mekonnen H., Ashenafi. M. and Adugna, T. 2013. Nutritive Value of Selected Browse and Herbaceous Forage Legumes Adapted to Medium Altitude Subhumid Areas of Western Oromia,
Ethiopia. Global Veterinaria, 11 (6): 809-816.

Duncan, B. D. 1955. Multiple Range Test and Multiple Test Biometrics 1:142.

Fajemisin, A. N., Chineke, A. J. and Alokan, J. A. 2012. Dietary effect of ensiled corncobs treated with or without water, lye and urea on performance characteristics of West African Dwarf sheep. Proceeding of $17^{\text {th }}$ Annual Conference of Animal Science Association of Nigeria held at International Conference Centre, Opposite Radio House, Area 8, Abuja, Nigeria. September 9-13 ${ }^{\text {th }}$ 2012. Pp. 575-578.

Fajemisin, A. N. 2015. Chemical composition and in vitro evaluation of the nutrient contents of Panicum maximum-Moringa oleifera diets. Nigerian Journal of Animal Production 42(2):197-208.

FAO. 2003. $h t t p: / w w w$.fao.org/ag/agap /frg/AFRIS/DATA/188.hmt. Assessed on 21st July 2015.

Getachew, M. B., Bailey, E., Borman, H., Ganskopp, D., Surber, G. and Harris, M. 2000. Factor and practices that affect livestock distributions. Range Land Management Practices, University of California Publication No.8217.

Ibeawuchi, J. A. Ahamefule, F. O. and Oche, J. E. 2002. An assessment of the nutritive value of the browsed plants in Makurdi, Nigeria. Nig. Agric. J.33:128-135.

Ibhaze, G. A. (2016). Reproductive performance of intensively managed primiparous gravid West African Dwarf goats fed pulverized bio-fibre waste-based diets. Nigerian Journal of Animal Production 43(2):133-138. 
Jokthan, G. E., Lakpini, C. A. M., Adamu, A. M. and Akpa, G. N. 2009. Effect of supplementing rice straw with Pigeon pea forage on the performance of Yankasa sheep. Nigeria Journal of Animal Production vol. 36 (11): pp134142.

Lamidi, A. A. and Ologbose, F. 2014. Dry season feeds and feeding: a threat to sustainable ruminant animal production in Nigeria. Journal of Agriculture and Social Research, 14(1):18.

Lorgyer, M. I., Odoh, O. E., Ikondo, N. D. and Okoh, J. J. 2009. Replacement value of Pigeon pea (Cajanus cajan) for maize on the performance of broiler finishers. Publication of Faculty of Agriculture, Nasarawa State University, Keffi, 1: 67-74.

McDonald, P., Edward, R. A., Grehaigh, J. F. D. and Morgan, C. A. 1998. Animal Nutrition. $5^{\text {th }}$ edition. Pearson Education Limited, Edinburg Gate, Garlow, Essex United Kingdom.

McDonald, P, Edwards, R. A., Greenhalgh, J. F. D. and Morgan, C. A. 2002. System for expressing the energy value of foods: Animal Nutrition. 6th Edn., Longman Group Ltd., UK., pp: 266-283

Meissner, H. H., Viljoen, M. O. and Van Niekerk, W. A. 1991. Intake and digestibility by sheep of Antherphora, Panicum, Rhodes and Smooth finger grass. In: Proc. $4^{\text {th }}$ International Rangeland Congress, September $17^{\text {th }}-21^{\text {st }}$, Montpellier, France.

Norton, B. W. 1994. Tree legumes as dietary supplements for ruminants. In: Gatteridge, R.C.,
Shelton, H.M. (eds): Forage tree legumes in tropical agriculture, $20^{\text {th }}$ Ed. CABI International Wallingford, U.K.

Norton, B. W., (2003). Tree legumes and Dietary supplements. In: Forages Tree Legumes in Tropical Agriculture, Gutteridge, R.C. and H.M Shelton, (Eds) CAB International, Wallingford, Oxon, pp:192-201

Preston, T. A. and Leng, R. A. 1995. Matching Ruminant Production Systems with available resources in the tropics and sub-tropics. Penambul Books, Armidale.

Raghuvansi, S. K. Prasad, R., Mishra, A. S., Chaturvedi, O. H., Tripathi, M. K., Misra, A. K., Saraswat, B. L. and Jakhmola, R. C. 2007. Effect of inclusion of tree leaves in feed on nutrient utilization and rumen fermentation in sheep. Bioresources Technology, 98:511-517.

Okeniyi, F. A., Aina, A. B. J., Onwuka, C. F. I. and Sowande, S. O. 2010. Nutrient digestibility of urea maize stover-based diets as dry season feed in WAD goats. Proc. 15th Conf. Anim. Sci. Assoc. of Nigeria, Univ. of Uyo, Nigeria, Pp.663-665.

Okoruwa, M. I., Adewumi, M. K. and Njidda, A. A. 2013. Nutrient utilization and growth performance of West African Dwarf goats fed with elephant grass or different proportions of plantain and mango peels. World $J$. Agric. Sci. vol 1(6): pp194-202.

SAS/STAT 1999. SAS User's guide: ver9.0. Statistical Analysis System Institute Inc.Cary, $\mathrm{NC}$.

Smart, J. I. 1996. Canavalia gladiate (Jacq) D.C. (Sword bean). Tropical pulses. Longman Group Ltd. London. Pp. 58 
Adebisi, Ajibike, Okunlola, Alalade, Amusa, Oladepo, Adeniyi and Mustapha

Sodamade, A., Bolaji, O. S. and Adeboye,

O. O. 2013. Proximate analysis, mineral contents and functional properties of Moringa oleifera leaf protein concentrate. Journal of Applied Chemistry, 4, 47-51.

Received: $13^{\text {th }}$ November, 2019

Accepted: $16^{\text {th }}$ February, 2020 